\title{
Foreign Ownership and Access to Bank Services in Indonesia
}

\author{
Rheinhard Yonathan, Dony Abdul Chalid*
}

\author{
Department of Management, Universitas Indonesia, Depok, Indonesia \\ *Corresponding author. Email: donny.abdul@ui.ac.id
}

\begin{abstract}
This study aims to analyze the effect of the presence of foreign banks on the access to bank services-in term of the number of automatic teller machines (ATMs), branch offices, and the allocation of credit distribution by banks - to micro, small, and medium enterprises (MSME) in Indonesia. We use data from 63 commercial banks in Indonesia spanning eight years, from 2010 to 2017 . We apply a panel data regression to conduct the estimation. This research found that the foreign ownership percentage of a bank does not have a significant effect on the number of ATMs. However, the effect on banks' branch offices is negative and significant. Moreover, the foreign ownership percentage has a negative influence on MSME lending. Foreign banks' method of entry through the acquisition of domestic banks or takeovers does not have a significant effect on the number of ATMs owned by banks. However, the effect is significant and positive on banks' branch offices. A greenfield method was found to have a significant influence on banking accessibility, as illustrated through the number of ATMs owned by banks; however, this effect did not occur for the number of bank branch offices and MSME lending.
\end{abstract}

\section{Keywords: Foreign Ownership, Financial Inclusion, MSME Loan, Bank}

\section{INTRODUCTION}

The importance of the role of banks in a country can also be observed through access indicators used to measure the level of financial inclusion in that country. The presence of banks indicated through the extent of the financial services that they provide through branch offices and ATMs is a benchmark used to measure financial inclusion levels based on access indicators in a country (Demirgüç-Kunt \& Klaper, 2013). The 2017 Global Findex report found that difficulty accessing formal financial institutions is why approximately $33 \%$ of the adult population do not have savings accounts in these institutions.

Along with the issue of financial inclusion, during the past two decades, the number of foreign banks that have penetrated developing countries has been increasing (Gopalan, 2018). This process is reflected in the increasing foreign penetration in a country's markets through Foreign Direct Investment or mergers and acquisitions. Foreign banks' penetration rate in developing countries was higher than the penetration rate of foreign banks in developed countries from 1995 to 2009. Their role in developing countries also cannot be ignored, considering that banks play an important role in these countries of carrying out the financial intermediation function (Peria and Mody, 2004; Claessens \& Van Horen, 2014).

Several previous studies indicated that foreign banks' entry contributes positively to carrying out their functions as providers of access to financial services. Foreign banks' entry can reduce the constraints that small and medium-sized companies face when to obtain funding (Clarke, Cull and Pería, 2006), increase credit supply, reduce interest rates and overhead costs (Beck, et al. 2010), positively affect the efficiency and competition of the banking sector (Cull and Peria, 2010), and advance financial access (Gopalan \& Rajan, 2018).

In contrast, several studies on developing countries revealed a negative impact of foreign banks. Foreign banks tend to serve small segments of the population (Beck \& Martinez Peria, 2010). Most foreign banks prefer to offer their credit to large and profitable companies and ignore borrowers who are not or less profitable and not creditworthy. Foreign banks tend to "cherry-pick" actions by choosing large companies that are transparent, profitable, and informative (Del'Ariccia \& Marquez, 2004, and Sengupta, 2007). Several 
empirical studies conducted in Latin American countries, India, and Pakistan proved that banks with foreign ownership limit their loans to small and medium enterprises relative to domestic banks (Clarke et al., 2005; Gormley, 2010; and Mian, 2006).

The presence of foreign banks increases access to credit, which arises from competition between these and local banks. However, the effects of the entry of foreign banks do not arrive at the home, and the majority of the poor still face very limited access to formal financial services (Ellis, 2007).

The empirical research on the impact of foreign ownership on access to financial services in Indonesia's banking industry is still limited. This research specifically examines the influence of the entry of foreign banks on public access to financial services through several indicators, including branch offices and number of ATMs, as well as loans received by the wider community that result from an increase in access to these financial services.

\section{LITERATURE REVIEW}

Several previous studies observed bank accessibility and the influence of foreign banks on bank accessibility. Beck et al. (2007) introduced a set of indicators on the most recent banking sector outreach and specifically measured access and use of savings and loan services. Based on data from 98 countries, this study showed that higher branch and ATM intensity in demographic and geographical terms led to greater access to the use of financial services by households and companies.

Beck and Martinez (2010) analyzed the influence of the presence of foreign banks in Mexico on banking outreach. In this study, the number of branch offices, deposits, and loans are used as an indicator of banking outreach. This study found that, although country- and bank-level estimates showed an increase in bank branches and the possibility of bank presence in various regions, only wealthier regions and urban areas benefited.

Gopalan and Rajan (2018) conducted research that focused on the influence of foreign banks on financial inclusiveness. Their study used two indicators to measure financial inclusion: access and usage. The usage indicator is illustrated by the number of ATMs and the number of branch offices, as was used in most recent studies. This finding found that foreign banks' entry could increase banking access, as was illustrated in the number of ATMs and branch offices. However, regarding the indicator of use, foreign banks' entry could hinder the use of financial services provided.

Several previous studies analyzed the effect of foreign ownership on MSME lending. Beck et al. (2001) used the latest data sets on Argentinian banks, companies, and loans to analyze the effects of bank size, foreign ownership, and pressure on lending to small businesses that had unclear information (opaque). Their results showed that large institutions and foreign ownership might create difficulties in extending loans to small companies that tend to have unclear or blurry information. Similarly, Clark et al. (2005) analyzed the allocation and growth of small business loans in Argentina, Chile, Colombia, and Peru and found that small businesses in countries with foreign bank participation are more likely to obtain credit from foreign banks that have a significant local presence.

Mian (2006) again found a negative influence of foreign banks on MSME lending. Gomley (2010) carried out research to determine the influence of foreign banks' entry into India during the 1990s. They found that, after entry, foreign banks finance only a small number of highly profitable companies, and the average company's chances of obtaining a loan after foreign banks' entry increased by only $8 \%$, given a systematic decline in domestic bank loans. Their study also found that the decrease in loans observed was more strongly felt by small companies.

De Haas et al. (2010) attempted to determine the effect of ownership in several transition countries in Europe on the allocation of business credit. The study determined that state-owned banks provide more loans to state-owned companies than do private banks and that the focus of foreign banks on foreign clients is limited to the corporate segment. The findings showed that foreign ownership in banks did not influence MSME loans. In contrast, bank size was found to significantly influence the allocation of credit to MSMEs. Degryse et al. (2012) attempted to determine, for banks in Poland, whether or not the influence of ownership on the allocation of credit given to small businesses is known by entrepreneurs. This study found that foreign banks that entered using greenfield or takeover methods made smaller credit allocations to small businesses than did domestic private banks.

Hamada (2018) conducted research on 90 commercial banks in Indonesia during 1998-2009. This study aimed to investigate the impact of foreign banks' acquisitions of domestic privately owned banks on loan behavior, especially SME loans. This study found that the entry of foreign banks - entering using both takeover and greenfield methods - had a significant and negative influence on lending to SMEs.

\section{RESEARCH METHOD}

We use an annual data panel of 63 public banks in Indonesia during 2010-2017. This commercial bank consists of four government-owned national banks, 31 privately owned national banks, 18 banks owned by foreign parties that entered through the takeover 
method, and ten banks owned by foreign parties that entered through the greenfield method. We use secondary data from the Indonesian Banking Directory issued by Bank Indonesia and the Otoritas Jasa
Keuangan and annual reports issued by commercial banks. The macroeconomic data used in this study were obtained from the World Bank website.

Table 1. List of variables

\begin{tabular}{|c|c|c|}
\hline Variable & Description & Indicator \\
\hline ATM & Total number of ATMs in a bank & Numbers of ATM \\
\hline Branch & Total number of branches to total assets & Branch $=\frac{\text { Number of Branches }}{\text { Total Asset }}$ \\
\hline MSME Credit & Loans given to MSMEs to total loans & MSME Loan Allocation $=\frac{M S M E \text { Loans }}{\text { Total Loans }}$ \\
\hline $\begin{array}{r}\text { Foreign } \\
\text { shares }\end{array}$ & $\begin{array}{l}\text { Number of shares owned by foreign investors } \\
\text { to total shares held by the bank }\end{array}$ & Percentage of foreign shares in a bank \\
\hline Takeover & & $\begin{array}{l}\text { dummy that equals } 1 \text { if a foreign bank enters by } \\
\text { acquiring a domestic bank }\end{array}$ \\
\hline Greenfield. & & $\begin{array}{l}\text { dummy that equals } 1 \text { if a foreign bank enters by } \\
\text { making a greenfield investment }\end{array}$ \\
\hline Return on Asset (ROA) & & $R O A=\frac{\text { Net Income }}{\text { Average total asset }}$ \\
\hline Size & natural logarithm of total assets & Size $=$ Ln $($ Total Asset $)$ \\
\hline $\begin{array}{l}\text { Non-Performing } \\
\text { Loan (NPL) }\end{array}$ & non-performing loans to total loans & $N P L=\frac{\text { Non }- \text { Performing Loan }}{\text { Total Loan }}$ \\
\hline GDP per Capita & Measures a company's economic growth & $\begin{array}{l}\text { Indonesian GDP per capita during the research } \\
\text { period }\end{array}$ \\
\hline Inflation & Measures economic stability & $\begin{array}{l}\text { Indonesian inflation rate during } \mathrm{n} \text { the research } \\
\text { period }\end{array}$ \\
\hline Real interest rate & $\begin{array}{l}\text { The nominal interest rate that has been } \\
\text { reduced by the inflation rate }\end{array}$ & $\begin{array}{l}\text { Indonesian real interest rate during the research } \\
\text { period }\end{array}$ \\
\hline
\end{tabular}

The first model uses the presence of ATMs in the community as an indicator of accessibility to financial services offered by banks.

ATMit $=\alpha 0+\beta 1$ Foreign Shareit $+\beta 2$ TakeOverit $+\beta 3 \mathrm{Gr}$ eenfieldit+

$\beta 4$ ROArit $+\beta 5$ Sizeit $+\beta 6$ NPLit $+\beta 7$ GDP_Capitait $+\beta 8$ Infla tionit+ $\beta$ 9Real_interest_Rateit $+\varepsilon$ it (1)

The second model uses the presence of bank branch offices in the community as an indicator of accessibility to financial services offered by banks.

Branchit $=\alpha 0+\beta 1$ Foreign_Shareit $+\beta 2$ TakeOverit $+\beta 3$ Greenfieldit+ $\beta 4$ ROArit $+\beta 5$ Sizeit $+\beta 6$ NPLit $+\beta$ 7GDP_Capitait $+\beta 8$ Infla tionit $+\beta$ 9Real_interest_Rateit + eit (2)

The third model uses credit distribution by commercial banks to MSMEs as an indicator of accessibility to financial services offered by banks. In addition, the purpose of using this model is to determine the effect of the presence of branch offices on the allocation of credit distribution by banks to MSMEs.

MSMEsit $=\alpha 0+\beta 1$ Foreign Shareit $+\beta 2$ TakeOverit $+\beta 3$ Greenfieldit+

$\beta 4$ ROArit $+\beta 5$ Sizeit $+\beta 6$ NPLit $+\beta 7$ GDP_Capitait $+\beta 8$ Infla tionit $+\beta 9$ Real_interest_Rateit + cit (3)

\section{RESULTS AND DISCUSSION}

Using the results of the Chow and Hausman tests, all three models are estimated with the random effect model. When conducting the multicollinearity test, a correlation table was used. A correction between variables higher than 0.75 indicated multicollinearity problems in the research model. TABLE III provides the correlation test results for the variables used in this research. 
Table 2. Descriptive Statistics

\begin{tabular}{|l|l|l|l|l|l|}
\hline Variable & Mean & Max & Min & SD & Obs \\
\hline ATM & 64598,87 & 202479 & 0,0000 & 57304,09 & 504 \\
\hline Branch & $7,51 \mathrm{E}-06$ & $3,96 \mathrm{E}-05$ & 0,0000 & $6,85 \mathrm{E}-06$ & 504 \\
\hline MSME Credit & 0,2787 & 0,9735 & 0,0000 & 0,2368 & 504 \\
\hline Foreign Ownership & 0,4516 & 0,9999 & 0,0000 & 0,4159 & 504 \\
\hline Takeover & 0,2857 & 1,0000 & 0,0000 & 0,4522 & 504 \\
\hline Greenfield. & 0,1587 & 1,0000 & 0,0000 & 0,3657 & 504 \\
\hline ROA & 0,0135 & 0,0515 & $-0,1115$ & 0,0183 & 504 \\
\hline Size & 16,2741 & 20,8432 & 11,7968 & 1,9877 & 504 \\
\hline NPL & 0,0234 & 0,2484 & 0,0000 & 0,0220 & 504 \\
\hline GDP per Capita & 3579,875 & 3877,00 & 3167,00 & 209,5997 & 504 \\
\hline Inflation & 0,05153 & 0,0641 & 0,0352 & 0,0111 & 504 \\
\hline Real interest rate & 0,0598 & 0,0922 & $-0,0174$ & 0,0320 & 504 \\
\hline
\end{tabular}

Table II provides the descriptive statistics for each variable used in the research. Some of the banks in Indonesia did not operate ATMs and did not have branch offices, and others did not provide credits to MSMEs.

Table IV provides the regression results of the random effect model for the first, second, and third models. The regression results of the three models are then used to test the research hypotheses and are explained in greater detail in the analysis and discussion for each hypothesis.

Table 3. Correlation Matrix

\begin{tabular}{|l|l|l|l|l|l|l|l|l|l|}
\hline & $\begin{array}{l}\text { Foreign } \\
\text { Share }\end{array}$ & $\begin{array}{l}\text { Take- } \\
\text { over }\end{array}$ & $\begin{array}{l}\text { Green- } \\
\text { field }\end{array}$ & Branch & ROA & Size & NPL & $\begin{array}{l}\text { GDP_ } \\
\text { CAPITA }\end{array}$ & $\begin{array}{l}\text { Infla- } \\
\text { tion }\end{array}$ \\
\hline Foreign Share & 1,00 & & & & & & & & \\
\hline Takeover & 0,59 & 1,00 & & & & & & & \\
\hline Greenfield & 0,44 & $-0,23$ & 1,00 & & & & & & \\
\hline Branch & $-0,51$ & $-0,06$ & $-0,47$ & 1,00 & & & & & \\
\hline ROA & $-0,08$ & $-0,14$ & 0,05 & $-0,01$ & 1,00 & & & & \\
\hline Size & 0,36 & 0,06 & 0,13 & $-0,45$ & 0,31 & 1,00 & & & \\
\hline NPL & 0,11 & 0,11 & 0,04 & $-0,14$ & $-0,39$ & 0,08 & 1,00 & & \\
\hline GDP_CAPITA & 0,03 & $3,70 \mathrm{E}-18$ & $1,76 \mathrm{E}-18$ & $-0,12$ & $-0,01$ & 0,07 & $-0,03$ & 1,00 & \\
\hline Inflation & $-0,03$ & $3,55 \mathrm{E}-19$ & $5,06 \mathrm{E}-18$ & 0,07 & 0,06 & $-0,03$ & $-0,15$ & $-0,40$ & 1,00 \\
\hline Real Interest Rate & 0,06 & $-4,93 \mathrm{E}-$ & $-4,42 \mathrm{E}-$ & $-0,21$ & $-0,13$ & 0,14 & 0,02 & 0,56 & $-0,11$ \\
\hline
\end{tabular}


Table 4. Results

\begin{tabular}{|c|c|c|c|}
\hline Variables & Number of ATMs & Number of Branches & MSME Loans \\
\hline & Coefficient & Coefficient & Coefficient \\
\hline $\mathrm{C}$ & $\begin{array}{l}-239807 \\
(0,000)\end{array}$ & $\begin{array}{l}5,69 \mathrm{E}-05 \\
(0,000)\end{array}$ & $\begin{array}{l}1,3041 \\
0,0000\end{array}$ \\
\hline FOREIGN_SHARE & $\begin{array}{l}5075 \\
(0,6606\end{array}$ & $\begin{array}{l}-5,17 \mathrm{E}-06 \\
0,0000 * * *\end{array}$ & $\begin{array}{l}-0,0814 \\
0,0767 *\end{array}$ \\
\hline TAKEOVER & $\begin{array}{l}-4586 \\
0,7021\end{array}$ & $\begin{array}{l}3,08 \mathrm{E}-06 \\
0,0452 * *\end{array}$ & $\begin{array}{l}-0,0338 \\
0,5554\end{array}$ \\
\hline GREENFIELD & $\begin{array}{l}-25594 \\
0,0814 *\end{array}$ & 0,7935 & $\begin{array}{l}-0,0334 \\
0,6773\end{array}$ \\
\hline LN-Branch Assets & & & $\begin{array}{l}0,0609 \\
0,0017 * * *\end{array}$ \\
\hline ROA & $\begin{array}{l}-433188 \\
0,0002 * * *\end{array}$ & $\begin{array}{l}1,42 \mathrm{E}-05 \\
0,1545\end{array}$ & $\begin{array}{l}0,9421 \\
0,0328 * *\end{array}$ \\
\hline SIZE & $\begin{array}{l}20000 \\
0,0000 * * *\end{array}$ & $\begin{array}{l}-2,99 \mathrm{E}-06 \\
0,0000 * * *\end{array}$ & $\begin{array}{l}-0,0309 \\
0,0056^{* * *}\end{array}$ \\
\hline NPL & $\begin{array}{l}81009 \\
0,3665\end{array}$ & $\begin{array}{l}-2,03 \mathrm{E}-05 \\
0,0100 * *\end{array}$ & $\begin{array}{l}0,0908 \\
0,0086^{* * *}\end{array}$ \\
\hline GDP_CAPITA & $\begin{array}{l}-8,8500 \\
0,3183\end{array}$ & $\begin{array}{l}5,25 \mathrm{E}-10 \\
0,4878\end{array}$ & $\begin{array}{l}4,91 \mathrm{E}-05 \\
0,1487\end{array}$ \\
\hline INFLATION & $\begin{array}{l}-231747 \\
0,0992 *\end{array}$ & $\begin{array}{l}6,44 \mathrm{E}-06 \\
0,5919\end{array}$ & $\begin{array}{l}1,0697 \\
0,0487 * *\end{array}$ \\
\hline $\begin{array}{l}\text { REAL_INTEREST_RA } \\
\text { TE }\end{array}$ & $\begin{array}{l}494757 \\
0,0000 * * *\end{array}$ & $\begin{array}{l}-2,01 \mathrm{E}-05 \\
0,0001 * * *\end{array}$ & $\begin{array}{l}0,2152 \\
0,3513\end{array}$ \\
\hline R-Squared & 0,4516 & 0,4768 & 0,1644 \\
\hline F-Statistic & 45,2109 & 50,021 & 9,2285 \\
\hline Prob(F-Statistic) & 0,0000 & 0,0000 & 0,0000 \\
\hline
\end{tabular}

$* 10 \%$ level of significance, $* * 5 \%$ level of significance, and *** $1 \%$ level of significance

We find that the foreign ownership percentage does not affect the number of ATMs in a statistically significant manner. This result is different from the results in Gopalan and Rajan (2018), who found that the presence of banks owned by foreign parties had a significant and positive influence on banking access as measured through the number of ATMs and the number of branch offices. This contradiction in results, particularly regarding the number of ATMs, may have been caused by the interbank ATM networking allowing ATMs to be used by various banks within this network, including foreign-owned and national and governmentowned banks. Several parties offer this type of ATM network for banks in Indonesia, such as ATM Bersama, ALTO, and Prima. In 2017, the combined number of
ATM units in the networks was approximately 185,994. This finding provides an indication that, at the end of the study period, $98.14 \%$ of banks included in the sample that provided ATM services not only used their ATMs but also were incorporated into the interbank ATM network, thus increasing their overall ATM network.

Banks' foreign ownership percentage has a negative and significant effect on the number of branch offices. This result is similar to that of Detragiache et al. (2008), who found that the presence of foreign banks is negatively associated with indicators of access to financial services, such as branch penetration. However, this result contradicted the result in Gopalan and Rajan (2018), who found that the presence of foreign banks 
had a positive influence and could improve banking accessibility, as illustrated through the number of branch offices.

The percentage of foreign ownership has a negative influence on UMKM credit allocation by a bank. This finding is in line with some of the other findings obtained from previous studies. Gopalan and Rajan (2018) found a negative influence between the presence of foreign banks and the dimensions of use on finance, where the presence of foreign banks was found to hinder the use of financial services offered. Gomley (2010) found a negative influence of foreign banks on the allocation of MSME credit by banks and that foreign banks' entry could reduce the allocation of credit to small businesses because these banks focused more on channeling their loans to more profitable companies. This result was also found by Berger et al. (2001) and Mian (2006), who identified a negative influence between banks' foreign ownership and MSME lending: foreign banks were found to serve larger and more transparent companies. This finding is also in line with Hamada (2018), who showed that foreign banks' entry into Indonesia during 1998-2009 harmed MSME lending. Detragiache et al. (2008) also found that foreign ownership has a significant and negative influence on MSME credit and suggested that foreign banks tend to serve and benefit large companies that are more transparent.

Foreign banks' strategy entering using takeovers does not have a significant effect on the number of ATMs and the allocation of MSME credit. However, the takeover method is found to have a significant and positive influence on the number of bank branch offices. The greenfield method of entrance by foreign banks, which does not require making acquisitions, has no significant influence on the number of branch offices and the allocation of MSME loans. The greenfield method was found to have a significant negative effect on the number of ATMs.

Foreign banks that enter through acquisitions have more branches. In accordance with several previous studies, foreign banks that enter by acquiring domestic banks have additional advantages through increases in capital and knowledge transfers (Clarke et al. 2005) and by obtaining more modern screening technology (De Haas et al, 2010), while still accessing soft information about their customers from the acquired domestic banks (Claeys \& Hainz, 2014). In addition, Beck and Martinez (2010) found that the presence of takeover banks in Mexico was associated with an increase in the number of bank branches, although they tended to be more concentrated in urban and wealthy regions. In contrast to acquisitions, foreign banks that enter without making acquisitions (greenfield) do not have a significant influence on the number of bank branches. This discovery is allegedly caused by the presence of several greenfield banks that have relatively large numbers of branch offices and greenfield banks that do not have branch offices. Thus, several greenfield banks have indicated a focus on larger segments, whereas other banks concentrate only on smaller segments.

In Indonesia, foreign banks' takeover and greenfield methods of entering had no significant effect on the allocation of MSME loans. This result contrasts with results in previous studies that found that method of entry by banks influenced lending to MSMEs, such as Degryse et al. (2012), who found that banks entering through greenfield investments had a negative influence on MSME credit allocation because they were inclined to lend to more transparent companies. In contrast, banks that entered through acquisitions were not found to have this problem. In addition, this finding also contrasts with Hamada's findings (2018) that indicated that takeover and greenfield banks harmed the allocation of MSME loans in Indonesia during 1998-2009. Even so, other studies found that foreign banks that are distinguished by their entry method have no influence on MSME credit allocation (De Haas et al. 2010).

The ROA has a negative and significant influence on the number of ATMs, indicating that banks with high profitability tend to have a smaller number of ATMs. Because ATMs represent a cost burden for a bank, it makes sense that a higher profitability bank tends to have a smaller number of ATMs. The allocation of MSME loans was found to have a negative and significant influence on bank size. This finding is in line with that of De Haas et al. (2010), who found that large banks use their comparative advantages when lending to large customers because they can exploit economies of scale to efficiently evaluate the available hard information on these customers. Small banks do not have this advantage given their limited size; they would like to lend to large companies, but their comparative advantage is in processing soft information on MSMEs. The NPL ratio has a negative and significant effect on the number of branch offices, which again shows that the results are in line with the arguments and research of Gopalan and Rajan (2018), who stated and proved that ATMs are a more cost-effective choice than opening branch offices. Based on the arguments and research, that a bank will feel more can be concluded.

Branch offices have a positive and significant influence on the allocation of MSME loans. This finding is in accordance with the opinion of Claessens and Van Horen (2014), who stated the importance of the role of banks as an intermediary for financial services in developing countries. This finding also agrees with that of Gopalan and Rajan (2018), who argued that narrower financial inclusion is viewed as an "outreach" of the banking sector-the extent to which the banking sector is able to meet the needs of a large segment of the population. In this study, this large segment refers to 
MSMEs in Indonesia, which represent $99.99 \%$ of the total business actors in Indonesia.

GDP per capita does not have a significant effect on the first and second models of the study. This finding is different from those of Gopalan and Rajan (2018), who showed that GDP per capita has a significant influence on indicators of banking accessibility-also illustrated by the number of ATMs and branch offices. The findings obtained in this study indicate that the level of economic development in Indonesia does not have a significant influence on the number of ATMs and branch offices of a bank. Economic development in Indonesia is not a factor that encourages a bank to increase its presence, as illustrated by data on the number of ATMs and branch offices.

GDP per capita does not have a significant effect on bank lending to MSMEs. This finding contrasts with the findings of De Haas et al. (2010), who determined that GDP per capita had a significant influence on the proportion of credit to MSMEs - a finding that indicates that MSMEs in Indonesia do not keep up with economic developments when carrying out their business activities. This effect may result from the large number of MSMEs in Indonesia that represents $99.99 \%$ of the total business actors in the country such that the demand from MSMEs for external funding was maintained even though economic development did not progress. In addition, the World Bank reports that not all MSMEs are accounted for in GDP, especially MSMEs in the informal sector, which is considered to be the reason GDP per capita does not affect MSMEs in Indonesia.

Inflation has a negative and significant influence on the number of ATMs, indicating that economic stability has an influence on the number of ATMs in Indonesia. This finding is in line with those of Detragiache et al. (2008), who revealed that inflation had a significant and negative influence on the geographical penetration of the number of ATMs. Moreover, inflation was found to have a significant and positive influence on banks' lending to MSMEs. The findings obtained are in line with those of Degryse et al. (2012), who indicated that inflation has a positive influence on lending to small businesses in Poland. Allegedly, the increase in inflation allowed MSMEs to receive more in loans from banks because the prices of goods increased, enabling banks' allocation of credit to MSMEs to increase.

Real interest rates have a positive influence on the number of ATMs, whereas branch offices are negatively affected by real interest rates. This influence indicates that banks carry out riskier lending and, thus, tend not to increase their outreach to large segments through branch offices because branch offices have higher costs than other approaches, such as ATMs (Gopalan \& Rajan, 2018), which adds risk to banks. The regression results also indicate that real interest rates do not significantly influence the allocation of credit to MSMEs. These findings are not the same as those found in previous studies that identified that real interest rates have a significant and positive influence on the allocation of credit to MSMEs (Degryse et al., 2012). Therefore, during the study period, in lending to MSMEs, banks in Indonesia were not affected by movements in real interest rates.

\section{CONCLUSION}

This study aims to analyze the effect of the presence of foreign banks on bank accessibility, as illustrated through the number of ATMs and branch offices and the allocation of credit distribution by banks to micro, small, and medium enterprises in Indonesia. When conducting research, researchers used 63 commercial banks in Indonesia as samples and a research period of eight years, from 2010 to 2017. The research used panel data. In this study, the presence of foreign banks is illustrated through a bank's foreign ownership percentage. In addition, similar to some previous studies, this study distinguishes foreign banks into two types based on their entry methods: foreign banks that enter through acquisitions of domestic banks or greenfield domestic banks.

The presence of foreign banks, as described through a bank's foreign ownership percentage, was found not to have a significant effect on banking accessibility, as indicated by the number of ATMs owned by banks. However, the effect was found to be significant and negative for a bank's branch offices. In MSME lending, the presence of foreign banks was found to be a significant and negative influence. Foreign banks' method of entry through the acquisition of domestic banks or takeovers has no significant effect on banking accessibility, as illustrated by the number of ATMs owned by banks. However, the effect is found to be significant and positive at branch offices owned by banks. This method does not give effect to the provision of credit to MSMEs. Foreign banks' method of entry without acquiring domestic banks or engaging in greenfield investments was found to have a significant influence on banking accessibility, as indicated by the number of ATMs owned by banks. However, this influence did not occur for the number of bank branch offices and MSME lending.

\section{ACKNOWLEDGMENTS}

This work was supported by PITMA Research Grant 2019 from the University of Indonesia.

\section{REFERENCES}

[1] Beck, T.,x Demirguc-Kunt,x A.,xMartinezxPeria, MS. Reaching.out:accessxtoxandxusexof bankingxservicesxacrossxcountries. 
JournalvofvFinancialxEconomicsx85(1), 2007, 234-266. doi: 10.1016/j.jfineco.2006.07.002

[2] Beck, T., Peria, M., Maria. Foreign.bankxparticipationxand.outreach:.evidence xfrom Mexico. JournalvofvFinancialvIntermediationv19(1), 2010, 52-73. doi: 10.1016/j.jfi.2009.03.002

[3] Berger,x AllenxN.,xUdell,xGregoryxF. Smallxbusinessxcreditxavailabilityxand relationshipxlending:xTheximportancexofxBankxO rganisationalxStructure.

ThexEconomic Journalx112(477), 2002, F32-F53. doi: 10.1111/1468-0297.00682

[4] Claessens,xStijn.,xVanxHoren,xNeeltje. xForeignxBanks:xTrendsxandxImpact. Journalxof Money,Credit,vandvBanking 46(1), 2014, 295-326. doi: $10.1111 /$ jmcb. 12092

[5] Claeys, S., Hainz, C. Acquisitionxversusxgreenfield:

Theximpactxofxthexmodexofxforeign bankxentryxonxinformationxandxbankxlendingxrat esv(WorkingvPapervSeriesv210). Stockholm: Sveriges Riksbank, 2007.

[6] Claeys,xS.,xHainz,xC.

Modesxofxforeignxbankxentryxandxeffectsxonxle ndingxrates: Theory andxevidence. JournalxofvComparativevEconomicsv42(1), 2014, 160-177. doi: 10.1016/j.jce.2013.01.009

[7] Clarke,xG., Cull, R., Martinez Peria, vM., vSanchez, S. BankxLendingxtoxsmallxbusinessxin LatinxAmerica: Doesxbankxoriginxmatters? JournalvofvBanking \& Financev2(5), 2005, 891911.

[8] Clarke,xG.,xCull,xR.,xPeria,

M. M. Foreignxbankxparticipation and accessxtoxcreditxacrossxfirmsxinxdevelopingxcou ntries. Journal of International Developmentv34(4), 2006, 774-795. doi: 10.1016/j.jce.2006.08.001

[9] Cull, R., Martinez, P., Maria S. ForeignxBankxParticipationxinxDeveloping

Countries, WhatxDo WexKnowxabout the DriversvandvConsequencesvofvThis Phenomenon? (Policy Research Working Paper 5398). Washington, D.C.: World Bank, 2010.

[10] Dahlan, S. Manajemen Lembaga Keuangan. "KebijakanxMoneterxdanxPerbankan." Jakarta: Lembaga

PenerbitxFakultasvEkonomixUniversitasxIndonesi a, 2005.

[11] De Haas, R., Ferreira, D., Taci, vA. Whatvdeterminesxthexcomposition of banks' loanvportfolios? Evidence vfromvtransitionvcountries. JournalvofvBanking \& Finance 34(2), 2010, 388-398. doi: 10.1016/j.jbankfin.2009.08.005

[12] Degryse, H., Havrylchyk, O., Jurzyk, E., Sylwester,vK. Foreign bank entry, credit allocation andxlendingxratesxinxemerging markets: Empirical vevidence xfrom xPoland. JournalvofvBanking \&Finance 36(11), 2012, 29492959. doi: 10.1016/j.jbankfin.2011.12.006

[13] Dell'Ariccia, G., Marquez, R.Information and vbank vcredit vallocation. Journal of Financial vEconomics 72 (1), 2004, 185-214. doi: 10.1016/S0304-405X(03)00210-1

[14] Demirguc-Kunt, A., Klapper, L. Measuring financial inclusion: Explainingx variation in use of financial services xacross and xwithin xcountries. Brookings Papers on Economic Activity 44(1), 2013, 279-340.

[15] Demirguc-Kunt, vA., vKlapper, vL., vSinger, vD., vAnsar, S., Hess, Jake Richard. The GlobalvFindexDatabase 2017: Measuring Financial Inclusion xand xthe xFintech xRevolution (English). Washington,v D.C.: vWorld vBank vGroup, 2018.

[16] Detragiache, E., Tressel, T., Gupta, P. Foreign banks in poor xcountries: Theory xand evidence. The Journal of Finance 63(5), 2008, 2123-2160. doi: 10.1111/j.1540-6261.2008.01392.x

[17] Gopalan, S., Rajan, R. S. Foreignx banksx and xfinancial xinclusion in emerging and developing economies: an empirical investigation. Journal of International Development 30(1), 2014, 559-583. doi: 10.1002/jid.3354

[18] Gormley, T. A. The impact of foreign bank entry v in emerging markets: evidence from India. Journal of Financial Intermediaton 19(1), 2010, 26-51. doi: 10.1016/j.jfi.2009.01.003

[19] Gujarati, D. N. Basic Econometrics International Edition. New York: McGraw Hill, 2003.

[20] Hamada, M. Impact of foreign bank entry on SME Credit in the Indonesian banking sector. Journal of Southeast Asian Economies 35(1), 2018, 50-78. doi: 10.1355/ae35-1f

[21] Hill, H. The Indonesian Economy, 2nd ed. Cambridge: Cambridge University Press, 2000.

[22] Leon, F., Zins, A. Regional foreign banks and financial inclusion: Evidence xfrom Africa. Economic Modelling. doi: 10.1016/j.econmod.2019.03.012, 2019. 
[23] Martinez, P., Maria, S., Mody, vA. How foreign participation xand market concentration impact bank spreads: Evidence from Latin America. Journal of Money, Credit and Banking 36(3), 2004, 511-537.

[24] Mian, Va. Distance constraints: The limits of foreign lending in poor economies. The Journal of Finance 61(3), 2006, 1465-1505. doi: 10.1111/j.1540-6261.2006.00878.x

[25] Molyneux, P., Nguyen, Linh H., Xie, Ru. Foreign bank entry in South East Asia. International Review of Financial Analysis 30, 2013, 26-35. doi: 10.1016/j.irfa.2013.05.004
[26] Otoritas Jasa Keuangan. Laporan Tahunan Keuangan Inklusif 2017. Retrieved from http://snki.e.,kon.go.id/wpcontent/uploads/2018/08/Laporan-KeuanganInklusif-2017_.pdf, 2018.

[27] Sengupta, R. Foreign entry and bank competition. Journal of Financial vEconomics 84(2), 2007, 502528. doi: 10.1016/j.jfineco.2006.04.002

[28]Yan,xS.,xMinggao,xS.,xZhong,xX.,xYing,xB.vxBa nkssizexandxsmall-and medium-sized venterprise $\mathrm{v}(\mathrm{SME}) \mathrm{v}$ lending: evidence $\mathrm{xfrom}$ xChina. World vDevelopment 37(4), 2009, 800-811. doi: 10.1016/j.worlddev.2008.07.014 